\title{
THE INFORMATION SEEKING AND PROCURMENT NEEDS OF ATTENDEES AT AN INDUSTRIAL TRADE SHOW
}

\author{
NC Bresler, School of Tourism \& Hospitality, University of Johannesburg
}

\begin{abstract}
Purpose: The purpose of this article is to describe what attracts visitors to an industrial trade show, and to profile them. This will enable the show organisers to attract the right mix of exhibitors and fulfil their dual role of satisfying the needs of both attendees and exhibitors and improve the role of exhibitions in the latter's marketing mix.

Problem investigated: The research seeks to elicit the attendance objectives of participants in order to ascertain their information seeking and procurement needs. This can be used to improve the marketing communication of both the organisers and exhibitors.
\end{abstract}

Research methodology: The research design is a multi method, descriptive study. A non probability, judgemental sample was drawn; 1020 interviews were conducted per Electra Mining Africa expo in 2004 and 2006. Both open ended and fixed response questions were posed and due to the similarity of responses, 300 per show were analysed. The researcher fulfilled a participant observer role to enhance the validity and reliability of the findings.

Findings/implications: The prime reason for visitation was to see what is new, discover, and gather information, and attendees were not disappointed in that. The trade shows attracted an informed, niche audience. Exhibitors gained access to key decision makers with buying influence. Attendees represented all roles in the buying process and intended to buy some capital items exhibited within the following year. Business contacts were made. The attraction and contact efficiency of the exhibition's were high and may result in conversion efficiency. In terms of market and geographical coverage it is a vertical international show.

Originality: This paper contributes to limited research conducted on trade shows, especially in South Africa. It is unique in that it describes the effectiveness of an industrial trade show from a demand perspective in order to improve the facilitating role of exhibition organisers. It develops a knowledge base for improved show participation and future comparative studies.

Conclusion: For effective communication to take place exhibitors need to align their objectives with those of attendees. Organisers must provide exhibitors with a profile of expected visitors to enhance their performance and improve show participation.

Key words and phrases: industrial trade show, vertical trade show, horizontal trade show, effectiveness of show participation, attraction of a trade show; attendance objectives of a trade show; role of trade show organisers; role of trade shows in the marketing mix, effective trade show communication.

\section{INTRODUCTION}

It would appear as if organisers of industrial shows generally provide an adequate support function with respect to the logistics of the exhibit itself, and in publishing the event. However, they do not seem to take it a step further. Ideally they should develop a knowledge base about visitors that would not only assist them in attracting the right mix of exhibitors, but would also assist exhibitors in improving their marketing communication. This will enhance the effectiveness of trade shows. As part of the literature study the article will describe the basic information seeking and procurement needs of attendees and explain how a number of factors influence these namely; 1) the attendance objectives of attendees, 2) the product and show type and 3) the buying tasks and buying stage. All of these relate to the job roles of attendees. But it is firstly necessary to define a trade show.

Trade shows (trade fairs) are events that bring together, in a single location, a group of suppliers that set up physical exhibits of their products and services from a given industry or discipline (O'Hara \& Herbig, 1993:18). Dudley (1990:17) uses the term trade events and defines it as follows; exhibitions organised to bring trade buyers and sellers together which exclude the general public. It thus draws an exclusive audience. It is a social system bounded by time (4 to 5 days which is declining) and 
space (a convention city; its exhibition hall, major hotels, restaurants) (Bello, 1992:63; University of Pretoria, 2004:4). The term exhibition or trade show will be used interchangeably. In South Africa (SA) the term confex is used for smaller exhibitions which are often linked to conferences (Grant Thornton, 2006:ii).

\section{THEORETICAL BACKGROUND}

According to the literature visitors appear to attend exhibitions with very clear ideas why they are there. They do not go to exhibitions to be sold to, but rather view exhibitions as an information gathering exercise (Smith, Hama \& Smith, 2003:414). Attendees at a health and safety exhibition in the United Kingdom (UK), ranked the reasons for visiting the exhibition as follows; to see new products/developments (53\%), to obtain technical or product information $(23 \%)$, to get up to date information on legislation (21\%), to try new products/demonstrations (19\%), to see new companies $(14 \%)$, to see a specific company or product $(10 \%)$, to make business contacts $(8 \%)$, to discuss specific problems/talk to experts $(5 \%)$, to compare products or services $(5 \%)$ and to get training information on products (5\%) (Blythe,1999:102-103). They thus seek information for non-buying and buying purposes which will be referred to as information and procurement needs. Factors influencing these needs will henceforth be discussed.

\section{The Influence of Attendance Objectives on Information and Procurement Needs}

Smith and Smith (1999:27) compared the objectives of distributor and end-user attendees at the largest show catering for woodwork machinery in the United States of America (USA). They asked respondents before the show, to rate the relative importance of two buying and eight non-buying attendance objectives on a scale of one to seven, where seven is very important and one, not at all important. The average ranking for both groups in terms of the two buying objectives was; make buying decisions (4.87) and place orders (3.29). For the eight non-buying objectives the average ranking for both groups were; see new products introductions (6.39), see product features (6.18), find new suppliers (5.74), gather competitive intelligence (5.27), invest in supplier relationships (5.17), educate employees (5.08), shop entire product lines (4.94) and discuss problems with supplier (4.71). Placing orders was rated by both distributors (2.89) and end-users (3.69) as the least important objective. The implications for exhibitors are that they should base their at-show communication on differences in buying motives and information needs of attendee categories, which is dependent on buying tasks and job roles (Bello, 1992:60 and Browning \& Adams, 1988:32). How the buying tasks and job roles of attendees influence their information needs with reference to product and show type will now be briefly explained.

\section{The Influence of Product and Show Type on Information and Procurement Needs}

Different shows attract different attendees. For example, at the health and safety exhibition referred to above, about a third (35\%) of the attendees had no role, and two thirds $(65 \%)$ some role in purchasing; only a quarter $(26 \%)$ were decision makers. At a UK auto-tech exhibition the split was almost equal (53\% no role and $47 \%$ some role) and final decision makers were 16.45 percent (Blythe, 1999:101103). Bello and Lohtia (1993:314) ascertained that at a USA/Canada industrial textile equipment show, about two fifths (42\%) of attendees had no role and three fifths $(58 \%)$ participated in one or more purchase decisions. Pitta, Weisgal and Lynagh (2006:159) say on average 70 percent of trade show attendees plan to buy products offered by exhibitors, 75 percent actually make a purchase, and 95 percent said the trade show influenced their buying decision.

Although many attendees do not participate in the buying decisions their firm's make, Godar and O'Connor (2001:78) are of the opinion that they are influencers. Attendees who plan to buy of the equipment exhibited within the following twelve months (net buying influences) ranges from 79 to 93 percent even though the final decision makers account for only 22 to 51 percent of attendees (Rosson \& Seringhaus, 1995:82). Exhibitors must thus use the show as a lead-generating exercise; as the first step in building relationships (Chonko \& Tanner, 1990:16). Blythe (1999:107) suggests that applying the marketing concept as opposed to the selling concept would improve the outcomes of exhibitions 
and Pitta, et al. (2006:156) state that integrating exhibit marketing into marketing communication would maximise the value of the promotion process.

The information needs of attendees do not only vary according to product type, but also according to the type of trade show. Trade shows may be classified in a matrix according to market and geographical coverage as illustrated in table 1. A vertical show is more focussed in terms of exhibitors and visitors, and generally encompasses all levels of personnel within a given industry (Shoham, 192:337). A horizontal show is more diversified but may cover one level of visitor across industries, such as professional engineers. Regional and vertical shows will attract a higher proportion of low level operating personnel than do national, international and horizontal shows (Godar \& O'Connor, 2001:82). Each type is selected to achieve different management objectives, for example vertical and national shows to develop new product/market segments, horizontal and regional shows to support selling activities, international and combined shows to identify new distributors (Kijewski, Yoon \& Young, 1993:291-292).

Table 1: Types of industrial trade shows

\begin{tabular}{|c|c|c|c|}
\hline \multirow{2}{*}{$\begin{array}{l}\text { Geographic } \\
\text { coverage }\end{array}$} & \multicolumn{3}{|c|}{ Market coverage; exhibitors and visitors } \\
\hline & Vertical; focussed & Combined & Horizontal; diversified \\
\hline Regional & Regional vertical & Regional combined & Regional horizontal \\
\hline National & National vertical & National combined & National horizontal \\
\hline International & International vertical & International combined & International horizontal \\
\hline
\end{tabular}

Source: Developed from Bello and Barczak, 1990:51, Godar and O'Connor, 2001:82, Kijewski, Yoon and Young, 1993:289; Shoham, 192:336.

Coming back to the job roles of attendees and their information or communication needs, how this impact on their buying tasks and how it differs in terms of the stages in the buying process, will now be highlighted.

\section{The Influence of Buying Tasks and Stage on Information and Procurement Needs}

Analyzing the job roles of attendees is a necessary first step in developing communication objectives and selling to a typical show audience (Bello \& Lohtia, 1993:331). The information and procurement needs of attendees do not only vary according to their attendance objectives, the show and product type, but also according to their buying tasks; are they prospecting or existing customers, and the buying stage; is it a straight or modified re-buy? Gopalakrishna and Lilian (1995:25) explain the impact of these factors on the communication objectives and effectiveness of show participation as reflected in table 2. Shows generally help to move customers and those prospecting through the buying process, and reduce the need for marketing communication activities after the show (Gopalakrishna, Lilien, Williams, \& Sequeira, 1995:79). It is also the most effective communication medium midway through the buying process, when shows meet the information needs of attendees and communication objectives of exhibitors better than advertising or personal selling. If goals are congruent, people are likely to seek similar outcomes. Because information about trading partners is shared towards the evaluation stage, the cost of transacting business is reduced for both buyers and suppliers. Sharland and Balogh (1996:61) argue that the more one knows about the goals, motives, and objectives of a trading partner, the fewer clauses need to be included in the contract; reducing the overall contracting cost. The customer type (active, curious and passive), relative newness of the product, market share and competitiveness will also influence the information needs of attendees, and a stage in the buying process may be skipped (Tanner, 2001:17). 
Table 2: Information and procurement needs based on buying tasks and stage in the buying process

\begin{tabular}{|c|c|c|c|}
\hline \multirow{2}{*}{$\begin{array}{l}\text { Buying task of } \\
\text { prospects/custome } \\
\text { rs buying stage }\end{array}$} & \multirow{2}{*}{$\begin{array}{l}\text { Information and } \\
\text { procurement needs; } \\
\text { direct and indirect }\end{array}$} & \multirow[t]{2}{*}{$\begin{array}{l}\text { Communication objectives } \\
\text { of seller }\end{array}$} & $\begin{array}{l}\text { Relative communication } \\
\text { effectiveness }\end{array}$ \\
\hline & & & Low $\quad$ High \\
\hline Need recognition & $\begin{array}{l}\text { Search for suppliers and } \\
\text { new contacts, initiate } \\
\text { relationships }\end{array}$ & $\begin{array}{l}\text { Prospecting, generate } \\
\text { ideas, competitive } \\
\text { intelligence }\end{array}$ & \\
\hline $\begin{array}{l}\text { Develop } \\
\text { specifications }\end{array}$ & $\begin{array}{l}\text { Gather technical product } \\
\text { information, gain } \\
\text { expertise }\end{array}$ & $\begin{array}{l}\text { Product performance } \\
\text { expectations, feature } \\
\text { comprehension, educate } \\
\text { buyers }\end{array}$ & \\
\hline $\begin{array}{l}\text { Search for and } \\
\text { qualify suppliers }\end{array}$ & $\begin{array}{l}\text { Solve problems, reduce } \\
\text { cognitive dissonance }\end{array}$ & $\begin{array}{l}\text { Lead generation, retain } \\
\text { credibility }\end{array}$ & \\
\hline Evaluation & $\begin{array}{l}\text { Compare suppliers, } \\
\text { confirm purchase } \\
\text { supremacy }\end{array}$ & $\begin{array}{l}\text { Qualify prospects, } \\
\text { performance } \\
\text { comprehension, present } \\
\text { sales message }\end{array}$ & \\
\hline Place order & $\begin{array}{l}\text { Negotiation terms, } \\
\text { customization }\end{array}$ & $\begin{array}{l}\text { Negotiate terms, close } \\
\text { sale }\end{array}$ & \\
\hline Purchase feedback & $\begin{array}{l}\text { Evaluate and reinforce } \\
\text { decision }\end{array}$ & $\begin{array}{l}\text { Reassurance, strengthen } \\
\text { relationships }\end{array}$ & \\
\hline
\end{tabular}

Based on: Godar \& O'Connor, 2001:79, Gopalakrishna \& Lilian, 1995:25; Sharland \& Balogh, 1996:61.

The effectiveness of participating in an industrial show can be determined in terms of tactical activities by measuring the attraction efficiency (the flow of the target audience through the firm's booth), the contact efficiency (performance of the booth personnel in terms of company objectives such as separating lookers from buyers, dealing with complaints and finding new dealers) and the conversion efficiency (ability of sales people to turn contacts into leads (Gopalakrishna \& Lilian, 1995:26-28). This article will report on the attraction and contact efficiency only, from information obtained from visitors, not exhibitors. It may be mentioned that there is a resemblance between the terms attraction and contact efficiency and the terms used to measure the audience quality of attendees to industrial shows, namely; audience interest factor, net buying influence and total buying plans (Browning \& Adams, 1988:32; Sashi \& Perretty, 1992:251).

\section{PURPOSE OF THE STUDY}

The paper seeks to elicit the attendance objectives of participants in order to ascertain their information seeking and procurement needs. It specifically analyses the prime purpose of their visit and how attendees differ in the way they participate in purchase decisions for products examined during the show. This can be used to improve the marketing communication of both the organisers and exhibitors.

\section{RESEARCH METHODOLOGY}

The research design consisted of a variety of methods; both qualitative and quantitative inquiry was used. Relevant literature and exhibition documentation were studied, discussions held with the organisers, and surveys were conducted during two exhibitions of Electra Mining Africa, which were held in 2004 and 2006 at NASREC in Johannesburg. The researcher was also a participant observer and interviewed 15 visitors and five other participants at both exhibitions. The qualitative data was elicited to understand the context, to manage the fieldwork, and to enhance the interpretation and recommendations. 
Electra Mining Africa is a mining, industrial, construction and power generating show, and is recognised as one of the three largest mining shows worldwide. In 2006 it attracted 670 exhibitors who filled $30500 \mathrm{~m}^{2}$ exhibition space with billions of Rands of equipment showcased in six exhibition halls, an arena and outside space to demonstrate earth moving equipment, enormous mining vehicles, large machinery for processing and conveying bulk material. The average number of exhibitors per exhibition for SA was 194 in 2004, and the average net space sold per exhibition was $5965 \mathrm{~m}^{2}$ (University of Pretoria, 2004:4-5). The show attracted exhibitors from 22 countries and 35429 visitors in 2006 (Electra Mining Africa, 2004 and 2006). It shares characteristics common to many industrial shows, runs over five days, and is presented every alternative year. The Department of Minerals and Energy (DME) runs a mining week concurrently with the exhibition, and the SA Institute of Mining and Metallurgy (SAIMM) presents three conferences during the week. Anglo Zimele, Anglo American's business development and empowerment initiative, also showcased the diversity of its SME BEE (small and medium enterprises and black economic empowerment) enterprises in 2006 . The show can be classified as a vertical (leaning towards combined) international show in terms of table 1.

University students interviewed visitors to uncover the reasons for their visits, and the extent to which their information needs were satisfied. The questionnaire contained structured and open-ended questions and was developed in consultation with research experts and the organisers. It was tested on the first day of the exhibition in 2004. Except for minor changes, the same questionnaire was used in 2006. Questionnaires were available in English and Afrikaans in 2004, but only in English in 2006. This may be seen as a limitation, because mines are in rural areas of SA where Afrikaans is the lingua franca.

The universe was all visitors to the exhibition in 2004 and 2006 who had been at the show for at least two hours. A non probability, judgemental sample was drawn. Each of the about 125 interviewers had to conduct a minimum of eight interviews each (in total about 1000 per exhibition) under supervision. Interviews were held on different days of the week, at different exhibition halls and at different times of the day, starting at 12:00 until 15:30. Interviewers were evenly spread amongst the exhibition halls, and had to rotate. Interviews were discontinued with visitors who had been interviewed. Interviewers worked in groups of two or three to improve participation. In SA, people attend exhibitions in groups of two to three (Grant Thornton, 2006:vi). Each member of a group could be interviewed by a different student, and one attendee was not singled out whilst the others had to wait.

At the time of interviewing about two thirds of the exhibition halls had been visited by the respondents as reflected in table 3 (for 2006) and they intended to visit most of the remainder of the exhibition halls as well. Three hundred questionnaires were systematically selected from the total of about 1000 per exhibition for analysis, because the responses were found to be similar whilst coding the open ended questions. The final sample for the surveys was thus, $300 \times 2=600$.

Table 3: Exhibition halls visited at the time of interviews in 2006

\begin{tabular}{|l|l|l|l|c|l|l|l|}
\hline Halls & Description of exhibition content & $\begin{array}{l}\text { Visited } \\
\text { by }\end{array}$ & $\%$ & $\begin{array}{l}\text { Intends } \\
\text { to visit }\end{array}$ & $\%$ & Total & $\%$ \\
\hline 5 & Mining and general industrial equipment & 219 & 73 & 39 & 13 & 258 & 86 \\
\hline 6 & $\begin{array}{l}\text { Mining and general industrial equipment; } \\
\text { big }\end{array}$ & 215 & 72 & 39 & 13 & 254 & 85 \\
\hline 7 & Power generation and electrical items & 189 & 63 & 57 & 19 & 246 & 82 \\
\hline 8 & International and general & 161 & 54 & 71 & 24 & 232 & 78 \\
\hline 9 & Machine tools & 163 & 54 & 71 & 24 & 234 & 78 \\
\hline 10 & Small, medium enterprises and USA inter & 107 & 36 & 87 & 29 & 194 & 65 \\
\hline Out & Outside exhibits & 118 & 39 & 75 & 25 & 193 & 64 \\
\hline
\end{tabular}

\section{ANALYSIS AND INTERPRETATION OF FINDINGS}

The findings are interpreted as they are presented for simplification purposes. A summary of the findings is presented at the end. 


\section{Main Attraction to Visit an Industrial Trade Show}

Visitors were asked to reveal the main purpose of their visit in an open ended format as it is more likely to uncover the benefits they are seeking, than when they are presented with a list of product attributes to rank or rate in order of importance (Botschen, Thelen \& Pieters, 1999:38-42). According to the findings summarised in table 4, non-selling motives were more important than selling motives which is similar to the findings by EXSA (2003:3) and the research discussed in the literature review above.

Table 4: The main purpose to visit a trade show in order of importance

\begin{tabular}{|c|c|c|c|}
\hline \multirow{2}{*}{ The main purpose to visit a trade show } & \multicolumn{2}{|c|}{ Importance } & \multirow{3}{*}{\begin{tabular}{|l|} 
Total \\
269
\end{tabular}} \\
\hline & \multicolumn{2}{|c|}{$2004 \quad 2006$} & \\
\hline To see what is new, discovery, to gather information; count & 152 & 117 & \\
\hline$\%$ within the year & $52.6 \%$ & $46.1 \%$ & \\
\hline$\%$ within the main reason & $56.5 \%$ & $43.5 \%$ & $100 \%$ \\
\hline Technology related reasons; count & 72 & 49 & 121 \\
\hline$\%$ within the year & $24.9 \%$ & $19.3 \%$ & \\
\hline$\%$ within the main reason & $59.5 \%$ & $40.5 \%$ & $100 \%$ \\
\hline Networking related reasons; count & 19 & 29 & 48 \\
\hline$\%$ within the year & $6.6 \%$ & $11.4 \%$ & \\
\hline$\%$ within the main reason & $39.6 \%$ & $60.4 \%$ & $100 \%$ \\
\hline Buying related reasons; count & 35 & 11 & 46 \\
\hline$\%$ within the year & $12.1 \%$ & $4.3 \%$ & \\
\hline$\%$ within the main reason & $76.1 \%$ & $23.9 \%$ & $100 \%$ \\
\hline $\begin{array}{l}\text { Exhibitors; to see clients and competitor intelligence; count } \\
\% \text { within the year }\end{array}$ & & $\begin{array}{l}\text { new } 10 \\
3.9 \%\end{array}$ & 10 \\
\hline$\%$ within the main reason & & $100 \%$ & $100 \%$ \\
\hline $\begin{array}{l}\text { To see things working and evaluate possible employers; } \\
\text { especially for students; count }\end{array}$ & 6 & 3 & 9 \\
\hline$\%$ within the year & $2.1 \%$ & $1.2 \%$ & \\
\hline$\%$ within the main reason & $66.7 \%$ & $33.3 \%$ & $100 \%$ \\
\hline Conference linked to Electra Mining Africa; count & 2 & 6 & 8 \\
\hline$\%$ within the year & $0.7 \%$ & 2.4 & \\
\hline$\%$ within the main reason & $25 \%$ & $75 \%$ & $100 \%$ \\
\hline Other; count & 3 & 29 & 32 \\
\hline$\%$ within the year & $1 \%$ & $11.4 \%$ & \\
\hline$\%$ within the main reason & $9.4 \%$ & $90.6 \%$ & \\
\hline Total, count $/ 100 \%$ & $289 / 100 \%$ & $254 / 100 \%$ & 543 \\
\hline
\end{tabular}

The ranking did not differ much when the reasons for visiting specific exhibition halls were compared and the visitation of most halls, reflected in table 3, is indicative of the attraction efficiency of the show. The findings also confirm the relatedness of the products and the classification as a vertical show. However, from 2004 to 2006 the relative importance of three reasons had decreased. The cross tabulation reveals the magnitude of the decrease within the category; buying has decreased by $52.2 \%$, technology by $19 \%$, and to see new things by $13 \%$. This reveals a deterioration of the audience quality, namely the interest factor (Browning \& Adams, 1988:32; Sashi \& Perretty, 1992:254). However, the number of respondents who attended for network related reasons has increased by $20.8 \%$, and conferences linked to the exhibition. The latter may be positive, but Williams (1998:64) cautions that fringe events may detract from the main exhibition. More attention should consequently be devoted to relationship building.

A number of visitors did not want to disclose the reason for their visit, and said it was private. The response rate diminished form $96.3 \%$ (289 of 300 ) to $84.6 \%$ (253 of 300 ) and this may be attributable to lack of interviewers' experience. Some respondents indicated that they fulfilled a dual role as buyers and sellers; which impacted on their attendance objectives (Smith \& Smith, 1999:27). For example, some came to source possible SME BEE suppliers from the Anglo Zimele business development enterprises. Smaller exhibitors who wished to export, availed of the support services 
from the Ministry of Customs and Excise and the DME, and engineering students came to sell their services to the most preferred employer. The concept that exhibitors and visitors may be sellers and buyers was investigated by Hansen (1996:41-45). Hansen elicited that the participation mode determines participation motives and one can not merely assume that exhibiters are equivalent to sellers, and visitors are equivalent to buyers. The consequences for the show organisers are that selling exhibitors, value the benefits from government export marketing assistance available at international trade shows more than selling visitors, who have limited trade show services available. They may consider offering additional benefits to selling visitors, by giving them access through joint booths, as they tend to be smaller (Hansen, 1996:50).

\section{Satisfying the Information Seeking Needs of Attendees; Attraction Efficiency}

Attendees were asked if they saw anything new in their field of work at the show, and if they did, to describe what they found to be new. More than two thirds $(69.2 \%)$ of the sampled respondents affirmed that they did see something new in 2006 and this is $6.1 \%$ more than in 2004 (63.1\%). This perception ranged from 62 to 73 percent as listed in table 5 . However, the exhibition halls that were perceived to offer more new products did not attract more visitors. This can only be ascribed to the strong brand awareness of the show being a mining exhibition since 1972 and the consequent strong relationships that had been fostered. Over time the exhibition moved away from being a pure vertical show towards a combined one as other related industries were included; SMEs were new in 2006. As far as the outside exhibition is concerned the low visitation may be attributed to the nature of the products. It catered for the demonstration of earth moving equipment, which would not be relevant to many attendees' job roles.

Table 5: See something new in their field of work at different exhibition halls in 2006

\begin{tabular}{|l|l|l|c|}
\hline Halls & Description of exhibition content & $\begin{array}{l}\text { See something } \\
\text { new }\end{array}$ & Visited \\
\hline 8 & International and general & $73 \%$ & $54 \%$ \\
\hline 10 & Small, medium enterprises and USA international & $73 \%$ & $36 \%$ \\
\hline 9 & Machine tools & $72 \%$ & $54 \%$ \\
\hline 7 & Power generation and electrical items & $71 \%$ & $63 \%$ \\
\hline 6 & Mining and general industrial equipment; big & $69 \%$ & $72 \%$ \\
\hline 5 & Mining and general industrial equipment & $68 \%$ & $73 \%$ \\
\hline Out & Outside exhibits & $62 \%$ & $39 \%$ \\
\hline
\end{tabular}

Many more respondents described what they found to be new; 150 in 2006 in comparison to 15 in 2004. The descriptions of what they found to be new were categorised into three groups from general to specific, namely; 1) very general, 2) specific product categories, and 3) very detailed descriptions. There was a large increase in the very detailed descriptions; from 10 to 82 . If the majority admit having seen something new, and can describe it in great detail, their primary objectives were probably met. However, inferences must be drawn with caution in the light of the improved elicitation of responses. The attraction efficiency of the exhibit halls was high which rendered visitors in a mood to listen and be receptive to exhibitors' messages. There would consequently be fewer interruptions from other show activities, in comparison to a sales call, and this could lead to improved contact and conversion efficiencies of show participation.

\section{Attendees Establish Business Contacts at a Trade Show; Contact Efficiency}

Attendees were asked to indicate if they came to the trade show to establish business contacts, and if so, to describe the type of contacts they established. In 2004, $69.8 \%$ of the selected respondents came to the trade show to establish business contacts and in 2006 it was $63.8 \%$, although only $11.4 \%$ (2004 and 2006) indicated that networking related reasons were the main purpose of their visit (Table 4). A third of respondents who answered the question (51 of 147: $34.7 \%$ ) described very specific contacts established in 2006. This may be reflective of purposive contacts and contact efficiency. Visitors to exhibition halls eight (international and general) and nine (machine tools) established more 
contacts than the average. This is also where respondents said they saw more new products. The trade show thus facilitated a cost effective way to establish international relations.

\section{Roles of Attendees at a Trade Show in the Buying Function; Net Buying Influence}

It is in the interest of exhibitors that visitors to trade shows have a role in purchasing, preferably a final say in the buying decision (Blythe, 1999: 102) and this is indicative of the quality of the show audience; and more specifically of the net buying influences (NBI) (Browning \& Adams, 1988:32; Sashi \& Perretty, 1992:251). Visitors represented all roles in the buying process, and some fulfilled more than one role. The proportion of selected respondents who did not disclose their roles have increased from $24.2 \%$ to $31.8 \%$, and it is assumed they had no role to play as indicated in table 6 . Only those who intended to buy of the exhibited equipment in the next year $(75.8 \%$ in 2006 and $68.2 \%$ in 2004 ; $\mathrm{NBI}$ ).were expected to disclose their roles.

Table 6: Net buying influences; role of attendees at a trade show in the buying function

\begin{tabular}{|c|c|c|c|c|c|}
\hline Role in the buying function & count & 2004 & count & 2006 & Total \\
\hline $\begin{array}{l}\text { Recognise the need to purchase the } \\
\text { equipment } \\
\text { \% within role/row }\end{array}$ & 85 & $\begin{array}{l}23.9 \% \\
51.8 \%\end{array}$ & 79 & $\begin{array}{l}22.5 \% \\
48.2 \%\end{array}$ & $\begin{array}{c}164 \\
100 \%\end{array}$ \\
\hline $\begin{array}{l}\text { Select and evaluate potential suppliers } \\
\% \text { within role/row }\end{array}$ & 65 & $\begin{array}{l}18.3 \% \\
47.4 \%\end{array}$ & 72 & $\begin{array}{l}20.5 \% \\
52.6 \%\end{array}$ & $\begin{aligned} 137 \\
100 \%\end{aligned}$ \\
\hline $\begin{array}{l}\text { Use the equipment in my department } \\
\% \text { within role/row }\end{array}$ & 66 & $\begin{array}{l}18.5 \% \\
57.4 \%\end{array}$ & 49 & $\begin{array}{l}14.0 \% \\
42.6 \%\end{array}$ & $\begin{array}{c}115 \\
100 \%\end{array}$ \\
\hline $\begin{array}{l}\text { Influence the specifications and the decision } \\
\% \text { within role/row }\end{array}$ & 60 & $\begin{array}{l}16.9 \% \\
53.1 \%\end{array}$ & 53 & $\begin{array}{l}15.1 \% \\
46.9 \%\end{array}$ & $\begin{array}{c}113 \\
100 \%\end{array}$ \\
\hline $\begin{array}{l}\text { Make the final decision } \\
\% \text { within role/row }\end{array}$ & 38 & $\begin{array}{l}10.7 \% \\
48.1 \%\end{array}$ & 41 & $\begin{array}{l}11.7 \% \\
51.8 \%\end{array}$ & $\begin{array}{c}79 \\
100 \%\end{array}$ \\
\hline $\begin{array}{l}\text { Place the order or issue the contract } \\
\% \text { within role/row }\end{array}$ & 31 & $\begin{array}{r}8.7 \% \\
50.8 \%\end{array}$ & 30 & $\begin{array}{r}8.5 \% \\
49.1 \%\end{array}$ & $\begin{array}{c}61 \\
100 \%\end{array}$ \\
\hline $\begin{array}{l}\text { Other } \\
\% \text { within role/row }\end{array}$ & 11 & $\begin{array}{r}3.1 \% \\
28.9 \%\end{array}$ & 27 & $\begin{array}{l}7.7 \% \\
71.1 \%\end{array}$ & $\begin{array}{c}38 \\
100 \%\end{array}$ \\
\hline Total & 356 & $100 \%$ & 351 & $100 \%$ & 707 \\
\hline $\begin{array}{l}\text { Total; multiple roles add up to more than } \\
100 \%\end{array}$ & $\begin{array}{c}180.7 \\
\%\end{array}$ & & $\begin{array}{c}176.4 \\
\%\end{array}$ & & \\
\hline Respondents who disclosed roles; NBI of 300 & 227 & $75.8 \%$ & 205 & $68.2 \%$ & \\
\hline
\end{tabular}

The decrease $(75.8-68.2=7.6 \%)$ in the NBI may indicate that more visitors were sent to the exhibition by their employers for education or reward purposes. This finding is congruent with the observation that attendees were more reflective of employment transformation and the demography of the SA population in 2006. More young black persons and more females were present. This resulted in some selection bias in that student interviewers were inclined to select young black respondents like them, instead of selecting attendees reflective of the composition of the show audience.

In 2006 there were fewer visitors who used the equipment in their departments (14.8\%). However, it does not appear to confirm that the attendees who disclosed their roles in the buying function came from higher hierarchical levels in the organisations they represented. Visitors from higher hierarchical levels tend to be more involved in purchasing decisions, especially with respect to innovative purchases as they have more negotiating and contracting responsibilities (Bello, 1992:61-62). To improve the effectiveness of show participation more attention should be devoted to provide information that will enhance competitiveness and reduce the overall contracting cost.

\section{Intention of Attendees to Buy Capital Items in the Next Year; Total Buying Plans}

Two thirds $(66.2 \%)$ of the attendees planned to buy some capital items exhibited within the next year, and the figure was almost the same (68.2\%) in 2004, which indicates a consistent audience quality. Browning and Adams (1988:32-33) and Sashi and Perretty (1992:254) refer to this measure of 
audience quality as Total Buying Plans (TBP). When visitors who intended to buy (169), were asked what type of equipment they intended to purchase, more than a half $(50.9 \%)$ gave very specific answers in 2006. More than a third (38.5\%) described a specific product category, whilst the rest came up with very general $(8.9 \%)$ to no answers $(1.8 \%)$. The proportion of visitors who responded and provided information was almost the same for 2004. It is thus likely that the show will move attendees through the buying stages and allow for the skipping of some stages which will lead to conversion efficiency. The findings confirm respondents' role in the buying center, which will enhance communication effectiveness and contribute to contact efficiency.

\section{Type of Show; Job Functions of Attendees and Industries they Represented}

Respondents were asked to indicate their job function by selecting the most appropriate one from a list of 17 commonly used in the mining and electrical engineering industries. Their job functions ranged for example from directors 36 , engineers 37 , technicians 35 , foreman 17 , general managers 15 , to buyers 14 , mine supervisors 14 , and metallurgists 10 , in 2006 . The heterogeneity of the show audience confirms the classification as vertical, and indicates that non-adaptive selling methods will be ineffective as each concern themselves with only certain aspects of a purchase decision (Bello, 1992:60-61.

More engineers (29 up to 37) and fewer technicians (46 down to 35) visited the exhibition in 2006 than in 2004. Engineers and technicians are more likely to use the show as a source of relatively narrowly procurement information. They may require more technical information to formulate alternative product solutions, whilst managers may seek transactional information associated with selecting sources, because of their negotiation and contracting responsibilities (Bello, 1992:70). The attendance figures by directors, general managers and mine managers remained fairly similar. However, these people may be less dependent on trade shows for procurement information as they generally have access to other information far beyond personal in-exhibit sources (Bello, 1992:61, 63, 71). It would thus appear as if the show is becoming more important for obtaining narrow information to make buying decisions. This would render the show a more effective communication instrument and result in a shift of the show curve in table 2, towards the right at the last stages of the purchase process.

The industries represented by respondents in 2006 were predominantly mining and engineering, but there seem to be a shift towards the other industries. The classification of the show may therefore be moving towards a combined show and become a more important event to test new products, support selling activities, source distributors and enhance distributor relationships (Kijewski, et al., 1993:291).

\section{Relationship Building and Satisfying Attendees' Expectations}

Visitors were requested to rate the halls they visited on a scale of 1 to 5 in terms of satisfying their expectations; 5 indicated "fully met expectations". The total quality index was calculated at $81.38 \%$ for 2006 and $85.87 \%$ for 2004 , which is good. The attraction can be described as experiential marketing. One respondent said; "Dit bly maar iets fantasties, jy kan dit nie oorvertel nie" (It is just so fantastic one cannot possibly describe it to someone else). One visitor described the repeat visit as follows; "Dit is die beste ooit, die laaste vier jaar merk ek 'n opwaartse groei. Uitstallers laat die masjiene iets doen" (It is the best ever, the last four years I noticed an upward growth. Exhibitioners let the machines do something).

Most respondents (96.3\%) indicated that they would revisit the show; the figure for 2004 was $98 \%$. However, only $51.1 \%$ were repeat visitors in 2006 and $44.7 \%$ in 2004 . The reasons why they would revisit, were a close reflection of why they came in the first place. As many as 89 of $293(30.4 \%)$ respondents indicated that they visit mining shows elsewhere in the world and $38.9 \%$ (114 of 293) that they attend local in-house shows, and taking into account the number of repeat visitors, the sample can be considered informed respondents.

More than half ( 145 or $52.9 \%$ ) of the visitors came for one day only, $28.5 \%$ (78) for two days, and rest (18.6\%) for more. The respective figures for 2004 were $57.3 \%, 21.2 \%$ and $21.5 \%$. As the proportion 
of visitors with dual roles had not been factored in, one should be cautious in making any inferences about days visited.

\section{SUMMARY FINDINGS}

The purpose of the research was to describe what attracts visitors to an industrial trade show, and to profile them. This will enable the show organisers to attract the right mix of exhibitors and fulfil their dual role of satisfying the needs of both attendees and exhibitors. This information can be used to improve the marketing communication of both the organisers and exhibitors. In summary, almost half of the attendees reported the prime reason for their visit was to see what is new, discover, and to gather information, and were not disappointed in that. The exhibitor company and product mix, as well as the industries they represent, was closely related in that attendees paid a visit to almost all the exhibition halls. It is thus a vertical show. The show attracted an informed audience. More than half of the visitors attended other shows and more than a quarter who responded to the question, attended overseas mining shows which confirms the classification as an international mining show. Attendees represented all roles in the buying process and almost three quarters of them intended to buy some capital items exhibited within the following year. About two thirds made business contacts. Through the show exhibitors gained access to key decision makers who had buying influence. Many came from upper levels in the hierarchy of the companies they represented, or use the equipment they came to see. The job functions of attendees were sufficiently narrowly defined (managers, engineers, technicians, buyers) for effective selling. Memorability of product information would be good and attendees receptive to information, which renders communication effective. Follow-up sales visits would thus be productive. A number of exhibitors fulfilled a dual role as sellers and buyers which improve the audience yield. Relationship building was effective, and 96.3 percent intended to return. The exhibition's attraction and contact efficiency was thus high and this may lead to satisfactory conversion efficiency. The show attracted a niche audience with high profit potential which rendered it effective from an organiser and exhibitor perspective.

\section{MANAGEMENT IMPLICATIONS AND RECOMMENDATIONS}

The organisers of trade shows should attract exhibitors that would satisfy the expectations of visitors' and provide them with relevant information how to enhance the effectiveness of their participation.

For effective participation to take place at trade shows exhibitors need to balance the selling and non selling content of communications, and align their objectives with those of attendees. Trade shows have a strategic advantage above direct marketing, and must be integrated as a component of marketing communication. Staff should equip themselves with relevant competitive information and elicit information of commercial value from attendees. The diversity in job functions at a vertical show requires an adaptive selling approach based on differences in purpose of visit and buying motives. It will reduce the buying cycle and is the key differentiator between successful exhibiters and those who are not. Exhibitors must inform, educate and build relationships, face to face. They must follow-up on leads to elicit what customers fear, desire and act on, to understand their needs accurately, and solidify the relationship. Trade shows are a form of experiential marketing, and exhibitors must immerse attendees in involvement with machine demonstrations, displays, and providing exciting technical information.

\section{CONCLUSION}

Organisers of trade shows aught to be in a position to provide exhibitors with information on expected visitors, especially with regard to their information and procurement needs. This will not only enhance their facilitating role, but enable exhibitors to align their communication objectives to those of attendees and thus improve the effectiveness of show participation.

\section{REFERENCES}

Bello DC. 1992. Industrial buyer behaviour at trade shows; implications for selling effectiveness. Journal of Business Research, 25:59-80. 
Bello DC \& Barczak GJ. 1990. Using trade shows to improve new product development. The Journal of Business \& Industrial Marketing, Summer/Fall, 5(2):43-56.

Bello DC \& Lohtia R. 1993. Improving trade show effectiveness by analyzing attendees. Industrial Marketing Management, 22:311-318.

Blythe J. 1999. Visitor and exhibitor expectations and outcomes at trade exhibitions. Marketing Intelligence and Planning, 17(2):100-108.

Botschen G, Thelen EM \& Pieters R. 1999. Using means-end structures for benefit segmentation: an application to services. European Journal of Marketing, 33(1/2):38-58.

Browning JM \& Adams RJ. 1988. Trade shows: an effective promotional tool for small industrial businesses. Journal of Small Business Management, Oct, 26(4):31-36.

Chonko LB \& Tanner Jr JF. 1990. Relationship selling at trade shows; avoid the seven deadly salespeople. Review of Business, Summer, 12(1):13-18. New York: St. John University.

Dudley JW. 1990. Successful exhibiting. UK: Kogan Page Limited.

Electra Mining Africa. 2004 \& 2006. Exhibition catalogue. Cape Town: National Publishing (Pty) Ltd.

EXSA. 2003. EXSA module 2 research study; Exhibitions as part of the marketing mix, local marketers' perceptions, November, 1-9. EXSA [Online] Available from: http://www.exsa.co.za [Accessed: 16/07/2007].

Godar SH \& O'Connor PJ. 2001. Same time next year; buyer trade show motives. Industrial Marketing Management, 30:77-86.

Gopalakrishna S \& Lilien GL. 1995. A three stage model of industrial trade show performance. Marketing Science, 14(1):22-42.

Gopalakrishna S, Lilien GL, Williams JD \& Sequeira IK. 1995. Do trade shows pay off? Journal of Marketing, July, 59:75-83.

Grant Thornton. 2006: EXSA research study: The size and impact of the exhibition industry in South Africa, executive summary, i-v. EXSA [Online] Available from: http://www.exsa.co.za [Accessed: 16/07/2007].

Hansen K. 1996. The dual motives of participants at international trade shows; an empirical investigation of exhibitors and visitors with selling motives. International Marketing Review, 13(2):3953.

Herbig P, O’Hara B \& Palumbo FA. 1998. Trade show: who, what, why? Marketing Intelligence \& Planning, 16(7):425-435.

Kijewski V, Yoon E \& Young G. 1993. How exhibitors select trade shows. Industrial Marketing Management, 22:287-298.

O'Hara BS \& Herbig PA. 1993. What do the exhibitors think? A personal selling perspective. Journal of Business and Industrial Marketing, 8(4):18-25.

Pitta DA, Weisgal M \& Lynagh P. 2006. Integrating exhibit marketing into integrated marketing communications. Journal of Consumer Marketing, 23(3):156-166.

Rosson PJ \& Seringhaus FHR. 1995. Visitor and exhibitor interaction at industrial trade fairs. Journal of Business Research, 32:81-90. 
Sashi CM \& Perretty J. 1992. Do trade shows provide value? Industrial Marketing Management, 21: 249-255.

Sharland A \& Balogh P. 1996. The value of non selling activities at international trade shows. Industrial Marketing Management, 25:59-66.

Shoham A. 1992: Selecting and evaluating trade shows. Industrial Marketing Management, 21:335341.

Smith TM \& Hama K \& Smith PM. 2003. The effect of successful trade show attendance on future show interest; exploring Japanese attendee perspectives of domestic and offshore international events. Journal of Business and Industrial Marketing, 18(4/5):403-418.

Smith TM \& Smith MS. 1999. Distributor and end-user trade show attendance objectives: an opportunity for adaptive selling. Forest Products Journal, 49(1):23-29.

Tanner JF Jr. 1994. Adaptive selling at trade shows. Journal of Personal Selling\& Sales Management, Spring, XIV(2):15-23.

University of Pretoria, 2004. EXSA module 3 research study: A situation analysis of the exhibition industry in SA (2002-2004) and international key trends, developments and best practice, executive summary, 1-7. EXSA [Online] Available from: http://www.exsa.co.za [Accessed: 16/07/2007].

Williams A. 1998. Adapting amid adversity. Asian Business, June, 34(6):62-68. 